\title{
Comments
}

\section{The Ninth Amendment: A Constitutional Challenge to Corporal Punishment in Public Schools*}

\section{INTRODUCTION}

On February 21, 2001, a third grader, Michael Setliff, received three blows to the buttocks with a wooden paddle for misbehaving at recess. ${ }^{1}$ Prior to the incident, Michael's parents had specifically requested that he not be physically punished. ${ }^{2}$ As a result of this event, Michael brought an action against the school board and principal, alleging that he was injured when his principal administered the punishment. ${ }^{3}$ The court held that the school board and principal were not responsible for Michael's injuries and found that their actions were far less severe than those of the teacher in Harrell v. Daniels, ${ }^{4}$ in which the court refused to award damages. ${ }^{5}$ In Harrell, the child who was paddled was taken to an emergency room shortly after the paddling. ${ }^{6}$ A medical report described two bluish-red bruises $2 \frac{1}{2}$ " by 3 " in width; one bruise was located on the buttocks and the other over the left flank. ${ }^{7}$ In refusing to award damages, the court in Harrell took into consideration that the student's behavior at school was disruptive, aggressive, and bizarre, and therefore merited such punishment. ${ }^{8}$ In relying on this holding, the Setliff court dismissed Michael's suit. The court stated that "by allowing corporal punishment, the legislature has recognized a need for such under certain

David R. Hague. I would like to extend my thanks to Professor Suzanne Carey McAllister for her suggestions and comments on previous drafts of this Comment. I would also like to thank Guillermo Zorogastua for his insightful comments and help throughout the editing process. Additionally, I owe much of this piece to my wife, Michelle - thank you for always supporting me.

1. Setliff v. Rapides Parish Sch. Bd., 888 So. 2d 1156, 1158 (La. Ct. App. 2004).

2. Id. at 1159 .

3. Id. at 1156 .

4. 499 So. $2 d 482$ (La. Ct. App. 1986).

5. Setliff, 888 So. $2 \mathrm{~d}$ at 1161 .

6. Id.

7. Id. (citing Harrell).

8. Id. 
circumstances,"9 and that "parents must yield to a higher duty, i.e., that which is best for all of the children, as well as those who have the enormous responsibility of educating them." 10

Michael was, in actuality, a fortunate child. His corporal punishment produced minor injuries when compared to many other instances of extreme punishment that occur each year. ${ }^{11}$ Such punishments inflicted on children in public schools may come as a surprise for many, especially parents with school-aged children. Do children really deserve to be beaten in school for minor disruptions? Are parents required to accept the physical and emotional scars that corporal punishment leaves on their children because it is purportedly in the "best interest" of the school system? Is there no constitutional protection available when such punishments are administered?

In 1977 the Supreme Court of the United States directly addressed the constitutionality of corporal punishment in Ingraham v. Wright. ${ }^{12}$ The Court held, in a five-to-four decision, that the cruel and unusual punishment clause of the Eighth Amendment applied only to criminal punishments and thus provided no protection against the imposition of corporal penalties by school authorities. ${ }^{13}$ The Court further held that the procedural due process guaranteed by the Fourteenth Amendment did not require schools to provide notice and a hearing before application of physical discipline. ${ }^{14}$

The Court's decision in Ingraham unfortunately fostered judicial indifference to corporal punishment in schools and essentially precluded constitutional challenges to such punishments based on the Eighth and Fourteenth Amendments. Unlike the issues addressed by the Supreme Court in Ingraham, however, this Comment argues that the Ninth Amendment provides a constitutional challenge to corporal punishment in public schools. Specifically, it argues that parental rights are a clear example of rights "retained by the people." 15 Because parents are charged with the upbringing of their children, they retain an intrinsic right to discipline their children accordingly. Although other articles and commentaries have continually addressed the issue of corporal punishment and have fashioned various arguments as to its

9. Id. at 1162 .

10. Id.

11. See discussion infra Part II.A.2.

12. 430 U.S. 651,653 (1977).

13. Id. at $668-69$.

14. Id. at 682.

15. U.S. CONST. amend. IX. 
unconstitutionality, ${ }^{16}$ they have failed to consider the implications of the Ninth Amendment and the protection it may provide to children.

Part II of this Comment discusses corporal punishment and examines its effects on children. In addition, it analyzes court decisions discussing the use of corporal punishment in public schools. Part II also sets forth the recognition and basis of parental rights and explains the source of this privilege. Finally, it provides background on the Ninth Amendment and discusses the competing interpretations. Part III argues and adopts the position that, based on the original intent of the Framers of the Constitution, the right to direct the upbringing of a child is a clear example of rights "retained by the people" and is a source of constitutional protection for the parent. In addition, it explains how the use of corporal punishment in public schools violates this fundamental right. Although Ingraham v. Wright precluded federal constitutional challenges to corporal punishment based on the Eighth and Fourteenth Amendments, a federal cause of action based on the Ninth Amendment remains. Thus, the continuing legal battle against corporal punishment should be revisited under this approach.

\section{BACKGROUND}

\section{A. Corporal Punishment}

Corporal punishment is defined as physical punishment on the body. ${ }^{17}$ More specifically, corporal punishment is the willful and

16. See, e.g., John Dayton, Corporal Punishment in Public Schools: The Legal and Political Battle Continues, 89 EDUC. L. REP. 729, 732-34 (1994) (discussing courts that recognize a valid cause of action based on substantive due process rights to be free from corporal punishment by public school officials); Andre R. Imbrogno, Corporal Punishment in America's Public Schools and the U.N. Convention on the Rights of the Child: A Case for Nonratification, 29 J.L. \& EDUC. 125, 138-43 (2000) (discussing a possible protection against corporal punishment by ratification of the U.N. Convention on the Rights of the Child); Jerry R. Parkinson, Federal Court Treatment of Corporal Punishment in Public Schools: Jurisprudence that is Literally Shocking to the Conscience, 39 S.D. L. REV. 276, 302-10 (1994) (discussing various problems with the federal courts' treatment of corporal punishment in public schools).

17. BLACK'S LAW DiCTIONARY 1269 (8th ed. 2004).

Past forms of corporal punishment included branding, binding, mutilation, amputation, and the use of the pillory and the stocks. It was also an element in such violent modes of execution as drowning, stoning, burning, hanging, and drawing and quartering .... In most parts of Europe and in the United States, such savage penalties were replaced by imprisonment during the late eighteenth and early nineteenth centuries, although capital punishment itself remained. Physical chastisement became less frequent until, in the twentieth century, corporal punishment was either eliminated as a legal penalty or restricted to beating with a birch rod, cane, whip, or other scourge. In ordinary usage the term now refers to such penal flagellation. 
deliberate infliction of physical pain on the person of another to modify undesirable behavior. ${ }^{18}$ Some of the more abusive forms that have been litigated include piercing the skin with pins, ${ }^{19}$ hitting with blunt objects, ${ }^{20}$ breaking bones, ${ }^{21}$ painful limb contortions, ${ }^{22}$ excessive exercise, ${ }^{23}$ and smacking across the genitals. ${ }^{24}$

The Supreme Court has upheld the use of corporal punishment in schools: "Teachers may impose reasonable but not excessive force to discipline a child." 25 Today, twenty-two states allow some form of corporal punishment while twenty-eight have banned the practice. ${ }^{26}$ States that forbid the administration "of corporal punishment in their public schools have eliminated the practice by statute or state regulation."27 "[T]he existence of corporal punishment [is contingent] upon the decisions made by policymakers at a level no broader than the state. Where state law prohibits schools from employing corporal punishment, local school administrators are ... prohibited from utilizing this form of discipline." 28 On the other hand, states that allow corporal punishment either do not address the matter "in their legislative codes or, if permitting the practice by statute, draft the statute in permissive, as opposed to mandatory terms, allowing, but not requiring, schools to utilize physical force in disciplining their students. ${ }^{, 29}$

Corporal punishment in school has been justified in several ways. Proponents point to the constructive effects corporal punishment is

Id. (quoting Gordon Hawkins, Corporal Punishment, in 1 ENCYCLOPEDIA OF CRIME AND JUSTICE 251 (Sanford H. Kadish ed., 1983)).

18. Comm. on Psychosocial Aspects of Child and Family Health, Am. Acad. of Pediatrics, Guidance for Effective Discipline, 101(4) PEDIATRICS 723-28 (1998), available at http:// aappolicy.aappublications.org/cgi/reprint/pediatrics;101/4/723.pdf.

19. Brooks v. Sch. Bd., 569 F. Supp. 1534, 1534 (E.D. Va. 1983).

20. Meyer v. Litwiller, 749 F. Supp. 981, 983-84 (W.D. Mo. 1990).

21. Crews v. McQueen, 385 S.E.2d 712, 712 (Ga. Ct. App. 1989).

22. Willoughby v. Lehrbass, 388 N.W.2d 688, 691 (Mich. Ct. App. 1986).

23. Waechter v. Sch. Dist. No. 14-030, 773 F. Supp. 1005, 1007 (W.D. Mich. 1991).

24. Mott v. Endicott Sch. Dist. No. 308, 713 P.2d 98, 98 (Wash. 1986).

25. Ingraham v. Wright, 430 U.S. 651, 661 (1977).

26. Corporal Punishment in School, FAMILY EDUCATION.COM, http://school.familyeducation. com/education-and-state/punishment/38377.html (last visited Aug. 21, 2006). The following states continue to permit corporal punishment in the classroom: Alabama, Arizona, Arkansas, Colorado, Florida, Georgia, Idaho, Indiana, Kansas, Kentucky, Louisiana, Mississippi, Missouri, New Mexico, North Carolina, Ohio, Oklahoma, Pennsylvania, South Carolina, Tennessee, Texas, and Wyoming. Id.

27. Imbrogno, supra note 16, at 125 n.2 (citing Susan H. Bitensky, Spare the Rod, Embrace Our Humanity: Toward a New Legal Regime Prohibiting Corporal Punishment of Children, 31 U. MiCH. J.L. REFORM 353, 353 n.4 (1998)).

28. Id. at 129 .

29. Id. 
thought to have on discipline and order. Those who favor corporal punishment argue it is a tool to deter students from misbehaving. ${ }^{30}$ It is argued that corporal punishment teaches a child appreciation and respect for authority and improves moral character. ${ }^{31}$ In addition, proponents suggest that corporal punishment is consistent with "the right of all students to receive an education, uninterrupted by a . . . disruptive student." 32 Some insist that corporal punishment is a desirable alternative to arguably more cruel punishments like suspension. ${ }^{33}$ However, proponents of corporal punishment often fail to analyze the detrimental effects that the punishment has on children.

\section{The Effects of Corporal Punishment on Children}

Years of research demonstrate that corporal punishment, especially in schools, is not effective in helping children control or change behavior. "[C]orporal punishment as a teaching method is simply ineffective, or, at best, no more effective than nonviolent disciplinary methods that do not carry the risk of individual and societal harm."34

Corporal punishment has been linked to violence among children. Many child psychologists and professional organizations believe that corporal punishment is related to forms of physical violence perpetrated against children and that it "leads to children's increased anger, aggression, and tolerance for violence, and ultimately, a more violent society." $" 35$ According to the American Academy of Pediatrics Task Force on Violence, "the risk of involvement with violence has been associated with corporal punishment, viewing violent television, exposure to domestic violence and child abuse, and hand-gun ownership." ${ }^{36}$ The Task Force noted: "no doubt exists that children are harmed when they witness violence-cognitively, emotionally, and developmentally. Exposure to violence and victimization are also strongly associated with subsequent acts of violence by the victim., ${ }^{37}$

\footnotetext{
30. Id. at 130 .

31. Leonard P. Edwards, Corporal Punishment and the Legal System, 36 SANTA Clara L. REV. 983, 990 (1996).

32. Imbrogno, supra note 16, at 130 (quoting Lansing K. Reinholz, A Practical Defense of Corporal Punishment in the Schools, in CORPORAL PUNISHMENT IN AMERICAN EDUCATION: READINGS IN HisTORY, PRACTICE, AND ALTERNATIVES 342, 346 (1979)).

33. Id.

34. Deana Pollard, Banning Child Corporal Punishment, 77 TUL. L. REV. 575, 578 (2003).

35. Id. at 577 .

36. Id. at $584-85$.

37. Id. (quoting Task Force on Violence, Am. Acad. of Pediatrics, The Role of the Pediatrician in Youth Violence Prevention in Clinical Practice and at the Community Level, 103 PEDIATRICs 173,
} 
"[C]hildren learn violence mainly by example, especially from persons they depend upon, and so it should come as no surprise that research shows many abused children becoming violent delinquents and criminals and, eventually, abusers of their own children." ${ }^{38}$ Teachers are an example to children; children rely on and trust them. Arguably, violence is a learned behavior. "When children are disciplined with severe corporal punishment . . . it is not surprising that they behave violently toward others." 39 In other words, corporal punishment may be linked to social learning because children "imitate the aggressive behavior of the individual inflicting the punishment upon them., 40

Studies also show a correlation between corporal punishment and substance abuse. "[C]hildren who are spanked and slapped are twice as likely to develop alcohol and other drug abuse problems . . ." "41 In fact, "spanking and slapping children is linked to increased rates of anxiety disorders, alcohol abuse, drug abuse, anti-social behavior, and to some extent, depression." ${ }^{42}$ It is not surprising that various organizations are attempting to halt the use of corporal punishment in an effort to reduce substance abuse. For example, The Nurturing Program for Families in Substance Abuse Treatment and Recovery's main objective is to eliminate substance abuse, and one of its intermediate objectives is to provide families with alternatives to corporal punishment. ${ }^{43}$

Corporal punishment has also been linked to bullying in schools. "Corporal punishment is a degrading and humiliating treatment. Some children, upon seeing an adult in authority behave this way toward a child, interpret it as a license for them to do the same. For this reason, the use of corporal punishment promotes bullying, cruelty and scapegoating among children." 44

Finally, opponents of corporal punishment argue that corporal punishment as a teaching tool undermines educational policies and have

179 (1999)).

38. Kerby T. Alvy, Violence Sets an Example, Project NoSpanK (2005), http:// www.nospank.net/alvy.htm.

39. Focus Adolescent Servs., Violence Leads to Violence, http://www.focusas.com/ Violence.html (last visited Aug. 20, 2006).

40. Imbrogno, supra note 16, at 131.

41. Spanking Linked to Substance Abuse, StOPSPANKING.COM, Oct. 7, 1999, http:// www.stopspanking.com.

42. $I d$.

43. Norma Finkelstein, Dep't of Health Promotion \& Educ., Nurturing Program for Families in Substance Abuse Treatment and Recovery, http://www.strengtheningfamilies.org $/ \mathrm{html} /$ programs_1999/34_NPFSATR.html (last visited Aug. 20, 2006).

44. Jordan Riak, Twenty Good Reasons to Stop a Bad Practice, http://oz.plymouth.edu/ /sandy/ spanking.html (last visited Aug. 20, 2006). 
stated that "legislators must ... consider the educational policy problems associated with corporal punishment." 45 For example, opponents argue that "[o]fficial state support for striking children in the public schools, [sic] and the inequitable administration of corporal punishment . . . conflict with legislative policies on child abuse, and on racial, economic, and gender equity." 46 Opponents also argue that corporal punishment is inconsistent with stated educational policies:

To the extent that education favors independence and personal responsibility, the internalization of social values and self-motivation, belief in the intrinsic joy and usefulness of all learning, and preference for cooperation, a belief in democracy and joint decision-making, and respect for the thoughts and feelings of others within a social group, corporal punishment is counterproductive. It teaches instead the value of aggressive physical action as a means of settling problems and relies on brute force by the powerful over the weak. It undercuts the image of teacher as exemplar of reasoned behavior, nurturing adult and creative problem-solver.

\section{Corporal Punishment and the Courts}

In Ingraham, the Supreme Court directly addressed the constitutionality of corporal punishment. ${ }^{48}$ The lawsuit in Ingraham was brought by two Florida junior high school students against officials of the school they attended and the superintendent of their school system, challenging the constitutionality of the specific punishment they had received. ${ }^{49}$ The facts in Ingraham indicated that children in the plaintiffs' junior high school were receiving extremely harsh punishments, sometimes resulting in severe injuries. ${ }^{50}$ For example, for being slow to respond to a teacher's instructions, one of the plaintiffs, Ingraham, received twenty blows with a paddle while he was held over a table. ${ }^{51}$ The paddling was so severe that he suffered a hematoma, which required medical attention and several days' absence from school. ${ }^{52}$ The other plaintiff, Andrews, was hit on the arm so hard that he did not regain

45. Dayton, supra note 16 , at 736 .

46. Id.

47. Id. (quoting Ronald T. Hyman \& Charles H. Rathbone, CORPORAL PUNishment IN SCHOOLS: READING THE LAW 20 (1993)).

48. Ingraham v. Wright, 430 U.S. 651, 653 (1977).

49. Id.

50. Id. at 657

51. Id.

52. Id. 
full use of it for a week. ${ }^{53}$ Other students testified regarding similar experiences. $^{54}$

Plaintiffs challenged the constitutionality of these severe punishments. The Court discussed whether corporal punishment in public schools constituted cruel and unusual punishment violating the Eighth Amendment and whether the Fourteenth Amendment required due process procedures before the administration of punishment upon students. ${ }^{55}$ In deciding the Eighth Amendment issue, the Court held that the language of the Eighth Amendment proscribed excessive harshness equally in fines, bails, and punishments, ${ }^{56}$ all of which had been associated traditionally with the criminal process, and thus was inapplicable to the paddling of students "as a means of maintaining discipline in public schools." "openness of the public school and its supervision by the community" provided sufficient protections against the cruel and unusual punishment of students. ${ }^{58}$ In deciding the Fourteenth Amendment issue, the Court found that "corporal punishment in public schools implicates a constitutionally protected liberty interest, but . . . the traditional commonlaw remedies are fully adequate to afford due process." ${ }^{, 59}$

The Ingraham Court may have been accurate, from a historical standpoint, in concluding that the Eighth Amendment did not apply outside the criminal context and that traditional common-law remedies were adequate to afford due process. However, what opponents find particularly disconcerting about the holding is the fact that the Court disallowed constitutional challenges based on the Eighth and Fourteenth Amendments to the use of corporal punishment in public schools, regardless of its severity.

The Supreme Court's appearance of indifference to schoolchildren suffering from corporal punishment has trickled down to both state and federal courts and has brought about an adverse affect on children. Consider, for example, the following cases where the use of corporal punishment did not merit constitutional challenges based on the Eighth and Fourteenth Amendments. In 2004, in a Tennessee public school, a five-year-old, special-needs student was hit with flyswatters and

\footnotetext{
53. Id.

54. Id.

55. Id. at 653

56. Id. at 664

57. Id.

58. $I d$. at 670

59. Id. at 672 .
} 
yardsticks on a daily basis. ${ }^{60}$ The plaintiffs suggested the student was also required to "drink water from a toilet." old boy was paddled for failure to turn in a homework assignment. ${ }^{62}$ When the child attempted to shield himself from a second blow of the paddle by placing his hands behind him, his principal broke the boy's arm. ${ }^{63}$ In a similar case in New Mexico, a nine-year-old girl was struck in the leg with a split wooden paddle while the teacher held the child upside down by her ankles. ${ }^{64}$ The split paddle "clapped" and "grabbed" the girl's leg, resulting in a cut in the leg and a permanent two-inch scar. ${ }^{65}$ The girl's teacher discovered her injuries when the teacher "noticed blood coming through [the child's] clothes." Michigan fifth-grade, special-education student with a congenital heart defect died after being forced to sprint a 350-yard "gut run" for "talking in line ... during recess." ${ }^{\prime 67}$ School officials were well aware of the child's "medical history, physical limitations, and doctor's orders" that the child was not to engage in "any forced exertion." 68

The facts in these cases apparently did not amount to "the elements of severity" 69 required to bring a constitutional challenge for corporal punishment because they were outside the criminal context. In other words, these courts likely followed the reasoning employed in Ingraham and held that such infliction of punishment was "reasonably necessary for the proper education and discipline of the child.",70

Fortunately, some judges are willing to consider a constitutional challenge to corporal punishment. ${ }^{71}$ For example, in 2005, a teacher in Florida subjected an autistic student to the following acts:

60. Rhodes ex rel. Rhodes v. Wallace, No. 1:05 CV 1020 T AN, 2005 WL 2114080, at *1 (W.D. Tenn. Aug. 26, 2005).

61. Id.

62. Crews v. McQueen, 385 S.E.2d 712, 713 (Ga. Ct. App. 1989).

63. Id. at 713-14.

64. Garcia v. Miera, 817 F.2d 650, 653 (10th Cir. 1987).

65. Id.

66. Id.

67. Waechter v. Sch. Dist. No. 14-030, 773 F. Supp. 1005, 1007 (W.D. Mich. 1991).

68. Id.

69. See Ingraham v. Wright, 430 U.S. 651, 658-59 (1977) (discussing elements of constitutional challenges to punishment in educational settings).

70. Id. at 670 .

71. See Thrasher v. Gen. Cas. Co., 732 F. Supp. 966, 967, 971 (W.D. Wis. 1990) (denying defendants' motion for summary judgment when a high school student was thrown into a blackboard by the teacher); see also Webb v. McCullough, 828 F.2d 1151, 1158-59 (6th Cir. 1987) (recognizing that excessive corporal punishment may rise to the level of a constitutional violation). 
(1) slapping him on the head; (2) grabbing him by the neck and choking him; (3) yelling at and intimidating him when he was non-complaint [sic] ... ; (4) placing [him] in a closet and turning off the lights; (5) striking him on the buttocks after he had wet his pants, resulting in a red mark; and (6) ridiculing and cursing at [him] when he hit himself on the head with his hand, saying "you stupid little ass . . . if you want to keep banging yourself on the head, then go ahead . . . because you deserve it." $" 72$

The court found that the child stated a claim for a constitutional violation. $^{73}$ Unfortunately, this case and other similar cases seem to indicate that the punishment children receive must be classified as abhorrent abuse before any constitutional consideration is given. ${ }^{74}$ In other words, the punishment must be so excessive as to be "shocking to the conscience." 75 As the Supreme Court stated: "there can be no deprivation of substantive rights as long as disciplinary corporal punishment is within the limits of the common-law privilege [to use reasonable force in disciplining children]." ${ }^{, 76}$

The decision rendered in Ingraham was a clear setback for opponents of corporal punishment. Since Ingraham, many lawsuits have arisen over the constitutionality of its use. Unfortunately, the movement toward the abolition of corporal punishment in public schools has made slow progress. The legal battle against corporal punishment continues; however, bringing a federal cause of action against its use in schools remains extremely difficult under our system of law. ${ }^{77}$

\section{B. The Recognition of Parental Rights}

Courts have recognized the existence of parental rights for centuries. However, nothing in the Constitution references family or parental

72. A.B. ex rel. Baez v. Seminole County Sch. Bd., No. 6:05CV8020RL31KRS, 2005 WL 2105961, at *2 (M.D. Fla. Aug. 31, 2005) (internal footnotes omitted).

73. Id. at *7.

74. Id.

75. Garcia ex rel. Garcia v. Miera, 817 F.2d 650, 656 (10th Cir. 1987) (holding that corporal punishments that are "so grossly excessive as to be shocking to the conscience violate [the student's] substantive due process rights, without regard to the adequacy of state remedies").

76. Neal ex rel. Neal v. Fulton County Bd. of Educ., 229 F.3d 1069, 1074-75 (11th Cir. 2000) (quoting Ingraham v. Wright, 430 U.S. 651, 676 (1977)) (alteration in original).

77. See Ingraham v. Wright, 430 U.S. 651, 651 (holding that the Eighth Amendment's Cruel and Unusual Punishment Clause does not apply to corporal punishment imposed as discipline in school and that due process "does not require notice and hearing prior to imposition of corporal punishment"). 
rights. ${ }^{78}$ Still, various jurisdictions conclude that there is a constitutional right to parent and make decisions regarding the welfare of one's child. For example, one court has stated that "[a]t the common law of England, a parent's right to custody and control of minor children was a sacred right with which courts would not interfere except where by conduct the parent abdicated or forfeited that right." 79 In addition, certain courts support the holding that the education and nurturing of a child is a fundamental freedom. For example, the Supreme Court of Oklahoma has recognized that "[a]t common law the principal duties of parents to their legitimate children consisted in their maintenance, their protection, and their education." 80 For this reason, "the parent . . . was vested with supreme control over the child, including its education."

The Supreme Court first upheld parental rights as constitutionally protected in the case of Meyer v. Nebraska. ${ }^{82}$ In this case, the Court struck down a statute that prohibited the teaching of foreign languages at an elementary school and reasoned that parents had a right to control the education of their children because educational choices are fundamental to the sphere of the family. ${ }^{83}$ Two years later in Pierce $v$. Society of Sisters ${ }^{84}$ the Court reinforced the barrier around the family when it invalidated an Oregon statute requiring parents to send their children to public schools. ${ }^{85}$ The Court stated that the right to bring up children is fundamental: "The child is not the mere creature of the State; those who nurture him and direct his destiny have the right, coupled with the high duty, to recognize and prepare him for additional obligations." ${ }^{" 86}$ As both cases illustrate, the Supreme Court has given parents great autonomy in directing the education and upbringing of their children. Nevertheless, like all rights, the freedom to direct the upbringing of a child is not limitless.

The Court did "not suggest that the Constitution relegates a child to the status of a mere chattel, to be treated or mistreated by his or her

\footnotetext{
78. Griswold v. Connecticut, 381 U.S. 479, 482 (1965) ("The association of people is not mentioned in the Constitution nor in the Bill of Rights.").

79. In re Appeal in Maricopa County, Juv. Action No. J-75482, 536 P.2d 197, 206 (Ariz. 1975) (en banc) (citing In re Hudson, 126 P.2d 765 (Wash. 1942)).

80. Sch. Bd. Dist. No. 18 v. Thompson, 103 P. 578, 578-79 (Okla. 1909).

81. Id.

82. 262 U.S. 390 (1923).

83. See id. at 400 (stating that "it is the natural duty of the parent to give his children education suitable to their station in life").

84. 268 U.S. 510 (1925).

85. Id. at 534-36.

86. Id. at 535 (emphasis added).
} 
parents according to their pleasure." ${ }^{, 87}$ "[A] parent shown by clear and convincing evidence to be unfit, abandoning, or substantially neglectful can be permanently deprived of all parental rights." 88 For example, in the case of Prince v. Massachusetts, ${ }^{89}$ a mother was arrested for having one of her children illegally sell religious materials on the street corners. $^{90}$ The mother's defense was that the law violated her right to bring up her child as she saw fit, "which for appellant [meant] to teach him the tenets and the practices of their faith."91 The Supreme Court accepted that "the custody, care and nurture of the child reside first in the parents, whose primary function and freedom include preparation for obligations the state can neither supply nor hinder." ${ }^{2}$ However, the Court also stated that "the family itself is not beyond regulation in the public interest .... A Acting to guard the general interest in youth's well being, the state as parens patriae may restrict the parent's control by requiring school attendance, regulating or prohibiting the child's labor, and in many other ways." ${ }^{93}$ Not only do limitations exist in a parentchild relationship, but the abdication of these rights is prevalent in every state.

Paradoxically, parents do not have a right to abuse their children, but they lack a constitutional right to prevent corporal punishment in schools. Certain courts hold that a parent's rights may be terminated "when there is a substantial erosion of the relationship between the parent and child which [is] caused at least in part by the parent's serious neglect, abuse, prolonged and unreasonable absence, unreasonable failure to visit or communicate, or prolonged imprisonment." 94 Actions for the termination of parental rights in the context of abuse, neglect, or dependency proceedings are extremely common in the child welfare adjudication system. ${ }^{95}$ In general, the purpose of such proceedings is to protect the child, rather than prosecute the parent. ${ }^{96}$ To terminate a parent's rights, certain courts hold that there must be evidence that a

87. In re J.P., 648 P.2d 1364, 1377 (Utah 1982).

88. Id.

89. 321 U.S. 158 (1944).

90. Id. at 161 .

91. Id. at 164 .

92. Id. at 166

93. Id. (footnotes omitted).

94. See M.L.B. v. S.L.J. ex rel. S.L.J., 519 U.S. 102, 108 n.1 (1996) (quoting Miss. CodE ANN. $\S 93-15-103(3)$ (1994)).

95. See infra notes $97-98$ and accompanying text (discussing case law involving unfitness proceedings).

96. San Joaquin County Dept. of Human Servs. v. Edward S., 58 Cal. Rptr. 2d 494, 497 (Cal. Dist. Ct. App. 1996). 
parent is unfit and that a termination of the parent's rights is in the child's best interest. ${ }^{97}$ The effect of an order terminating a parent's rights is to sever all the parent's constitutional rights to the child, in effect divesting the parent from family-member status as related to the child. ${ }^{98}$

Despite the above-mentioned limitations, the Supreme Court recognizes many constitutional protections vested in parents over their children, and, having never been overturned, Meyer and Pierce are currently good law. Courts have protected this privilege from the 1920s to today, thus embedding it in our common-law tradition.

\section{The Ninth Amendment}

\section{Rights Retained by the People}

The Ninth Amendment declares that " $[\mathrm{t}] \mathrm{he}$ enumeration in the Constitution, of certain rights, shall not be construed to deny or disparage others retained by the people." 99 The text, on its face, arguably implies the rights protected by the Constitution are not limited to its express provisions. This inference invites a possible view that under the Ninth Amendment, judges are authorized to protect both express and unenumerated rights. Nevertheless, Ninth Amendment rights have always been somewhat elusive. ${ }^{100}$ As Justice Jackson of the Supreme Court stated, "the Ninth Amendment rights which are not to be disturbed by the Federal Government are still a mystery to me."101

In 1965, in the case of Griswold v. Connecticut, the Supreme Court established a constitutional right of privacy. ${ }^{102}$ In his concurring opinion, Justice Goldberg stated, "this Court has had little occasion to interpret the Ninth Amendment." "103 Because there was no precedent to guide the

97. See, e.g., Craven v. Doe, 915 P.2d 720, 724 (Idaho 1996) (holding that there was substantial competent evidence that supported termination of parental rights due to abandonment, neglect, and the best interest of the parent and child under Idaho law); DKM v. RJS, 924 P.2d 985, 987-88 (Wyo. 1996) (discussing showing of parental unfitness under Wyoming law).

98. Bazzetta v. McGinnis, 902 F. Supp. 765, 771 (E.D. Mich. 1995), aff'd, 124 F.3d 774 (6th Cir. 1997).

99. U.S. CONST. amend. IX.

100. Russell L. Caplan, The History and Meaning of the Ninth Amendment, 69 VA. L. REV. 233, 233 (1983).

101. Id. (quoting Robert H. Jackson, The Supreme Court IN THE AMERICAN System of GOVERNMENT 74-75 (1955)).

102. 381 U.S. 479, 485 (1965); see also John A. Lynch, Jr., Justice Douglas, the Chesapeake \& Ohio Canal, and Maryland Legal History, 35 U. BALT. L.F. 104, 106 (2005) (noting that Griswold established the constitutional right of privacy).

103. Id. at 490 (Goldberg, J., concurring). 
Court, Justice Goldberg consulted what he believed was the original understanding of the founders. ${ }^{104}$

In Griswold, the Court held that a Connecticut statute criminalizing the use of contraceptives was unconstitutional. ${ }^{105}$ "In his opinion for the Court, Justice Douglas wrote that the statute[] violated the right of marital privacy created by the penumbral rights emanating from specific guarantees in the first, third, fourth, fifth, and ninth amendments." However, it was Justice Goldberg's opinion that placed the interpretation of the Ninth Amendment into sudden discussion. ${ }^{107}$ Justice Goldberg stated that "[t]he language and history of the Ninth Amendment reveal that the Framers of the Constitution believed that there are additional fundamental rights, protected from governmental infringement, which exist alongside those fundamental rights specifically mentioned in the first eight constitutional amendments." 108 He went on to explain that the Ninth Amendment was specifically passed to "quiet the expressed fears that a bill of specifically enumerated rights could not be sufficiently broad to cover all essential rights and that a specific mention of certain rights would be interpreted as a denial that others were protected." ${ }^{109}$ Justice Goldberg did, however, recognize that the Ninth Amendment did not constitute

an independent source of rights protected from infringement by either the States or the Federal Government. Rather, the Ninth Amendment shows a belief of the Constitution's authors that fundamental rights exist that are not expressly enumerated in the first eight amendments and an intent that the list of rights included there not be deemed exhaustive. ${ }^{110}$

Since Griswold, several Supreme Court decisions have alluded to Ninth Amendment rights without further explaining exactly what unenumerated rights the Ninth Amendment might include. ${ }^{11}$ The

104. See id. at 488-90 \& n.4 (reviewing statements made by James Madison, Alexander Hamilton, and Justice Story regarding the adoption of the Ninth Amendment).

105. Id. at 485 (majority opinon); see also Caplan, supra note 100, at 224.

106. Caplan, supra note 100, at 224-25 (citing Griswold, 381 U.S. at 482-86 (Goldberg, J., concurring)).

107. See id. at 225 ("But it was Justice Goldberg's concurring opinion, joined by Chief Justice Warren and Justice Brennan, that catapulted the ninth into sudden respectability.").

108. Griswold, 381 U.S. at 488 (Goldberg, J., concurring).

109. Id. at $488-89$.

110. Id. at 492 .

111. Caplan, supra note 100, at 225-26 (citing Richmond Newspapers, Inc. v. Virginia, 448 U.S. 555, 579 n.15 (1980); Richmond Newspapers, 448 U.S. at 606 (Rehnquist, J., dissenting); Planned 
reluctance of the Court to further explain the interpretation behind the Ninth Amendment is difficult to understand. Not surprisingly, competing interpretations exist over the meaning of the Ninth Amendment.

\section{Competing Interpretations of the Ninth Amendment}

"Two interpretations of the Ninth Amendment dominate the current debate over its proper application." "12 First, the "unenumerated rights" view, which follows Justice Goldberg's approach, states that the Ninth Amendment clearly "protects judicially enforceable unenumerated rights." 113 In other words, under the Ninth Amendment, courts may enforce rights that are not explicitly written in the Constitution, ${ }^{114}$ such as statutory rights as well as common law rights.

The second interpretation, the "limited government" view, states that the Ninth Amendment "clarifies that the list of enumerated rights in the first eight amendments does not grant the federal government residual or unenumerated powers." "115 Stated differently, no individual "can use the existence of the Bill of Rights to argue that the federal government has powers which the Constitution does not specifically list."116 Those that support the "limited government" view would likely argue that "the Constitution does not give the federal government the power to appoint state court judges and the Due Process Clause of the Fifth Amendment cannot justify granting the federal government that power."117

Parenthood v. Danforth, 428 U.S. 52, 60 (1976); Buckley v. Valeo, 424 U.S. 1, 59 n.67, 84 n.113 (1976) (per curiam)). But see Lubin v. Panish, 415 U.S. 709, 721 n.* (1974) (Douglas, J., concurring) ("But the right to vote in state elections is one of the rights 'retained by the people' by virtue of the Ninth Amendment as well as included in the penumbra of First Amendment rights."); Palmer v. Thompson, 403 U.S. 217, 233-34 (1971) (Douglas, J., dissenting) (noting that "the right of the people to education or to work or to recreation ..., like the right to pure air and pure water, may well be rights 'retained by the people' under the Ninth Amendment.").

112. Cameron S. Matheson, The Once and Future Ninth Amendment, 38 B.C. L. REV. 179, 184 (1996) (citing Raoul Berger, Suzanna and-the Ninth Amendment, 1994 BYU L. REV. 51 (1994); Thomas B. McAffee, The Original Meaning of the Ninth Amendment, 90 Colum. L. REv. 1215 (1990); Suzanna Sherry, The Ninth Amendment: Righting an Unwritten Constitution, 64 CHI.-KENT L. REV. 1001 (1988)).

113. Matheson, supra note 112, at 184 .

114. Id

115. Id. at 185 .

116. Id. (citing McAffee, supra note 112, at 1307).

117. Id. 


\section{a. Unenumerated Rights View}

Supporters of the "unenumerated rights" view maintain this position with three main arguments: "a historical, a contextual and a textual argument." 118 The historical view is based on the Framers' intent in enacting the amendment. As indicated previously, the Framers believed that there were additional fundamental rights, which were protected from governmental intrusion, and that to overcome the fears of a bill that only listed specific rights, the Ninth Amendment was enacted. ${ }^{119}$ In other words, people feared that listing some rights in the Constitution would imply that no other rights existed. ${ }^{120}$ Thus, from a historical standpoint, proponents conclude that the Ninth Amendment clearly protects unenumerated rights.

The contextual argument states that the "limited government" argument renders the Ninth Amendment superfluous because, under that interpretation, "it would be identical to the Tenth Amendment." 21 "The Tenth Amendment safeguards the system of enumerated powers by reserving to the states and the people all powers not expressly given to the federal government."122 Thus, opponents of the "unenumerated rights" interpretation that support the contextual argument would conclude that one should not read the Ninth Amendment as identical to the Tenth Amendment. Justice Marshall further provides support for this view: "It cannot be presumed that any clause in the constitution is intended to be without effect." 123

Finally, the textual argument claims that the basic meaning of the text supports the "unenumerated rights" view and counters any "limited government" view. ${ }^{124}$ Proponents of the "unenumerated rights" view focus directly on the text of the amendment. Specifically, that the Ninth Amendment, "with its message, as plain as one might hope for given the vagaries of language," stands for the idea "that the specification of some

\footnotetext{
118. Id. (citing Sanford Levinson, Constitutional Rhetoric and the Ninth Amendment, 64 CHI.KENT L. REV. 131, 140-42 (1988)).

119. See supra notes $105-10$ and accompanying text.

120. Id.

121. Matheson, supra note 112, at 185.

122. Id. The Tenth Amendment states: "The powers not delegated to the United States by the Constitution, nor prohibited by it to the States, are reserved to the States respectively, or to the people." U.S. CONST. amend. X.

123. Marbury v. Madison, 5 U.S. (1 Cranch) 137, 174 (1803).

124. Matheson, supra note 112, at 186.
} 
rights was not to be interpreted as denying the equal presence within the legal system of other, unenumerated rights."125

According to this textual argument, "the plain language of the Ninth Amendment forecloses the 'limited government' view." 126 Although the Tenth Amendment speaks of powers, "the Ninth refers to rights."127 The Constitution does not assign the government authority "in certain areas even if legislation would not otherwise violate people's individual rights." 128 However, the Constitution does "grant power to the federal government in certain areas where legislation might violate individual rights." 129 Therefore, "the Tenth Amendment limits the federal government's power but does not protect individual rights." ${ }^{30}$ However, the Ninth Amendment "protects the rights of the people by limiting the means that the federal government can choose to achieve enumerated powers." 131 This textual distinction, therefore, indicates to the "unenumerated rights" advocates "that the Ninth Amendment limits the government in a substantially different way than the Tenth Amendment." 132

\section{b. Limited Government View}

Like the unenumerated rights proponents, supporters of the "limited government" view "support their position with historical, contextual and textual arguments." 133 Accordingly, "the key to discovering the meaning of the Ninth Amendment lies in the debate over the inclusion of a bill of rights in the Constitution."134 "According to the "limited government" [perspective], Federalists feared including a bill of rights in the Constitution for only one reason."135 These Federalists expressed apprehension that "the inclusion of a bill of rights would imply that the federal government had powers beyond those enumerated in the

\footnotetext{
125. Id. (quoting Levinson, supra note 118, at 141).

126. Id. at 186 (citing Levinson, supra note 118, at 142).

127. Id. (citing Levinson, supra note 118, at 142).

128. Id. (citing Levinson, supra note 118, at 142).

129. Id. (citing Levinson, supra note 118, at 142).

130. Id. (citing Levinson, supra note 118, at 142).

131. Id. (citing Levinson, supra note 118, at 186).

132. Id. (citing Levinson, supra note 118, at 142).

133. Id. at 187 (citing McAffee, supra note 112).

134. Id. (citing McAffee, supra note 112, at 1237).

135. Matheson, supra note 112, at 187 (citing McAffee, supra note 112, at 1250, 1259-60,
} $1285)$ 
Constitution." 136 According to "limited government" supporters, Madison's speech discussing the function of the Ninth Amendment does not refer to specific unenumerated rights, but rather raises the concern that "enumerating exceptions to federal power would imply that powers not denied by the bill of rights would be 'assigned into the hands of the General Government.",137 "Limited government" proponents conclude that Madison proposed the Ninth Amendment to remedy this fear. ${ }^{138}$

The contextual argument states:

$[T]$ he "limited government" interpretation does not render the Ninth Amendment superfluous because the "limited government" does distinguish between the Ninth and Tenth Amendments. According to this interpretation, "the Tenth Amendment clarified that the federal government was one of enumerated powers. The Framers designed the Constitution as a limited grant of power to the federal government. Before inclusion of the Tenth Amendment, the Constitution did not explicitly state the limited nature of its grant of power; however, Article I had hinted at this design. According to proponents of the "limited government" view, the Ninth Amendment clarified that the Bill of Rights in no way altered the federal system of enumerated powers. Thus proponents of the "limited government" view contend that the Tenth Amendment remedied the threat posed by the lack of an express constitutional provision stating that the federal government could exercise only enumerated powers while the Ninth Amendment remedied the threat posed by a bill of rights. ${ }^{139}$

The final argument upholding the "limited government" view of the Ninth Amendment, the "textual argument," states that

the Ninth Amendment limits the federal government to its enumerated powers [regardless of] the fact that it refers to "rights" and the "people." According to the "limited government" [theory], the Framers used the terms "powers" and "rights" almost interchangeably . . . . $[T]$ herefore, some commentators conclude that the text of the Ninth Amendment does not foreclose the "limited government" interpretation. ${ }^{140}$

136. Id. (citing McAffee, supra note 112, at 1250, 1259-60, 1285).

137. Id. (quoting McAffee, supra note 112, at 1285).

138. Id. (citing McAffee, supra note 112, at 1283-85).

139. Id. at $187-88$ (internal citations omitted).

140. Id. at 188 . 


\section{ANALYSIS}

\section{A. Parental Rights Preserved by the Ninth Amendment}

Because the "unenumerated rights" view focuses on the Framers" intent and the pure text of the Amendment, it provides a superior analysis in establishing parental rights. This argument is consistent with Justice Goldberg's concurring opinion in Griswold v. Connecticut, ${ }^{141}$ which the Court has never overturned and arguably remains a valid interpretation of the Ninth Amendment. Not surprisingly, courts have identified the Ninth Amendment as a source of constitutional protection for parental rights. ${ }^{142}$ By enacting the Ninth Amendment, the Framers' undeniably intended to secure parental rights as an "enduring American tradition."143

Is it sufficient to assume Framers of the Constitution, and the individuals who voted it into existence, meant exactly what it says? The Supreme Court has expressed its view regarding constitutional interpretation by stating that

there is a well settled rule which we must observe. The object of construction, applied to a constitution, is to give effect to the intent of its framers, and of the people in adopting it. This intent is to be found in the instrument itself; and when the text of a constitutional provision is not ambiguous, the courts, in giving construction thereto, are not at liberty to search for its meaning beyond the instrument. To get at the thought or meaning expressed in a statute, a contract, or a constitution, the first resort, in all cases, is to the natural signification of the words, in the order of grammatical arrangement in which the framers of the instrument have placed them. If the words convey a definite meaning, which involves no absurdity, nor any contradiction of other parts of the instrument, then that meaning, apparent on the face of the instrument, must be accepted, and neither the courts nor the legislature have the right to add to it or take from it. So, also, where a law is expressed in basic and unambiguous terms, the legislature should be intended to mean what they have plainly expressed, and consequently no room is left for construction. ${ }^{144}$

141. 381 U.S. 479, 486-99 (1964) (Goldberg, J., concurring).

142. See In re J.P., 648 P.2d 1364, 1377 (Utah 1982) (discussing the Ninth Amendment and its relation to parental rights).

143. See Wisconsin v. Yoder, 406 U.S. 205, 232 (1972) (stating that the " fundamental interest of parents' in the upbringing of their children is an enduring American tradition").

144. Lake County v. Rollins, 130 U.S. 662, 670-71 (1889). 
The Ninth Amendment protects rights "retained by the people." 145 The phrase "retained by the people" is apparent on the face of the amendment. ${ }^{146}$ Because "[t]he simplest and most obvious interpretation of a constitution ... . is the most likely to be that meant by the people in its adoption," $" 147$ it is proper to discuss the English and early-American common law when evaluating constitutional protections, such as parental rights. ${ }^{148}$ By discussing the rights held by the people at the time the Ninth Amendment was enacted, one may deduce which rights the Framers intended to retain. Illustrative of this idea is the 1935 case of Dimick v. Schiedt, ${ }^{149}$ where the Court discussed the meaning of the Seventh Amendment. In so doing, the Court stated that "[i]n order to ascertain the scope and meaning of the Seventh Amendment, resort must be had to the appropriate rules of the common law established at the time of the adoption of that constitutional provision in 1791."150 Hence, the question to ask is whether parental rights at common law were consistently recognized as rights "retained by the people."

In English common law, "a parent's right to custody and control of minor children was a sacred right with which courts would not interfere except where by conduct the parent abdicated or forfeited that right." A plurality of the Supreme Court has stated "the interest of parents in the care, custody, and control of their children ... is perhaps the oldest of the fundamental liberty interests recognized by this Court." ${ }^{152}$ Moreover, "“[ $t$ ]he history and culture of Western civilization reflect a strong tradition of parental concern for the nurture and upbringing of their children." 153 " "This primary role of the parents in the upbringing of their children is now established beyond debate as an enduring American tradition." "154

The intent of the Ninth Amendment was to encompass parental rights. This argument is strongly supported by the American common law presumption that parents were in the position to act out of an interest

\footnotetext{
145. U.S. CONST. amend. IX.

146. Id.

147. Id. at 671 .

148. See generally Daniel E. Witte, Comment, People v. Bennett: Analytic Approaches to Recognizing a Fundamental Parental Right Under the Ninth Amendment, 1996 B.Y.U. L. REV. 183 (1996) (providing an analytical framework of the original intent approach).

149. 293 U.S. 474 (1935).

150. Id. at 476 .

151. See supra note 79 and accompanying text.

152. Troxel v. Granville, 530 U.S. 57, 65 (2000) (plurality opinion).

153. Id. at 66 (quoting Wisconsin v. Yoder, 406 U.S. 205, 232 (1972)).

154. Id. (quoting Yoder).
} 
shared with their child. "It is fundamental to our jurisprudence that "the custody, care and nurture of the child reside first in the parents.",155 "Early common law, as well as many modern common law decisions, protected parental rights by in effect presuming not only that parents shared a common interest with children, but that the state shared a common interest with the parent."156 Early common law required the state first to show that the "child, state, and parental interests were disparate, and second to show that some interest was sufficiently compelling to override parental custody."157 In other words, just "because the decision of a parent [was] not agreeable to a child or because it involves risks [did] not automatically transfer the power to make that decision from the parents to some agency or officer of the state." 158 Stated boldly, "the statist notion that governmental power should supersede parental authority in all cases because some parents abuse and neglect children is repugnant to American tradition.","159

Critics may argue that by relying on the original intent approach the judicial system focuses on outdated and inapplicable principles. ${ }^{160}$ However, a departure from the import and meaning of the language used to express intent jeopardizes the Constitution's integrity. By looking for probable meanings not clearly embraced within the language of the text, one risks falling into the trap of misinterpretation. In People v. Purdy, Justice Bronson commented on such danger:

In this way a solemn instrument, for so I think the constitution should be considered, is made to mean one thing by one man, and something else by another, until in the end it is in danger of being rendered a mere dead letter; and that, too, where the language is so plain and explicit that it is impossible to make it mean more than one thing, unless we first lose sight of the instrument itself and allow ourselves to roam at large in the boundless field of speculation. For one, I dare not venture upon such a course. Written constitutions of government will soon come to be regarded as of little value, if their injunctions may be thus lightly overlooked; and the experiment of setting a boundary to power, will prove a failure. ${ }^{161}$

\footnotetext{
155. In re J.P., 648 P.2d 1364, 1372 (Utah 1982) (quoting Prince v. Massachusetts, 321 U.S. $158,166(1944))$.

156. Witte, supra note 148, at 220.

157. Id. (citing Davier v. Jurney, 145 A.2d 846, 849 (D.C. 1958)).

158. Parham v. J.R., 442 U.S. 584, 603 (1979).

159. Witte, supra note 148 , at 220.

160. Id. at 221 (citing Roberts v. Ward, 493 A.2d 478, 481 (N.H. 1985)).

161. People v. Purdy, 2 Hill 31, 36 (N.Y. Sup. Ct. 1841), rev'd on other grounds, 4 Hill 384
} 
Words are intended to convey a definite meaning. They are the "common signs that mankind make use of to declare their intention to one another; and when the words of a man express his meaning plainly, distinctly and perfectly, we have no occasion to have recourse to any other means of interpretation." 162 Thus, where a writing is "expressed in plain and unambiguous terms, whether those terms are general or limited, the legislature should be intended to mean what they have plainly expressed, and consequently no room is left for construction." 163

Moreover, these critics have failed to recognize recent courts' applications of this interpretative tool to the language of the Ninth Amendment. For example, in discussing the language of the Ninth Amendment, Justice Oaks of the Utah Supreme Court stated that " $[\mathrm{t}] \mathrm{he}$ rights inherent in family relationships-husband-wife, parent-child, and sibling - are the most obvious examples of rights retained by the people." "164 He went on to further state that these rights "are 'natural,' 'intrinsic,' or 'prior' in the sense that our Constitutions presuppose them, as they presuppose the right to own and dispose of property."

This parental right transcends all property and economic rights. It is rooted not in state or federal statutory or constitutional law, to which it is logically and chronologically prior, but in nature and human instinct. Thus, the United States Supreme Court has declared that "the liberty interest in family privacy has its source ... in intrinsic human rights ... , 166

Supporters of the "unenumerated rights" view maintain their position with several theories. These arguments focus on the plain meaning of the text and the Framers' intent in enacting the amendment. ${ }^{167}$ As demonstrated by both recent cases and those dealing with early common law, there is ample reason for courts to rely on the "unenumerated rights" view. The Framers believed in the existence of additional fundamental rights, which were protected from governmental intrusion. The "unenumerated rights" approach yields a clear picture that parental rights are constitutionally protected under the Ninth Amendment.

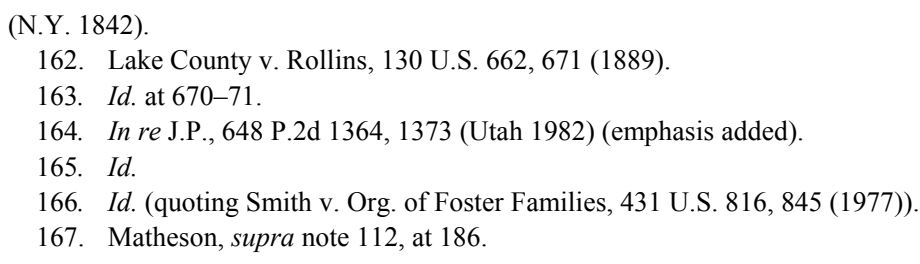




\section{B. Corporal Punishment in Public Schools as a Violation of the Ninth Amendment}

The Supreme Court in Ingraham held that the cruel and unusual punishment clause of the Eighth Amendment applied only to criminal punishments and did not provide protection against the imposition of corporal penalties by school authorities. ${ }^{168}$ The Court further held that the procedural due process guaranteed by the Fourteenth Amendment did not require schools to provide notice and a hearing prior to application of physical discipline. ${ }^{169}$ The Court's decision precluded constitutional challenges to corporal punishment because it focused solely on the rights of the child under the Eighth and Fourteenth Amendments. However, the Court did not foreclose the argument of whether a federal cause of action based on parental rights was available in a corporal punishment case. Specifically, they did not discuss whether the administration of such punishment in public schools violated the Ninth Amendment.

Because courts have generally accorded parental rights great judicial deference, courts have found these rights to operate against the state. However, some limitations apply. Analysis of whether the use of corporal punishment violates this constitutionally protected right requires an analysis of such limitations. "In determining whether the state has violated the childrearing rights of parents, a court balances the rights of the parent with those of the child and the parens patriae interest of the state." ${ }^{\prime 70}$ Such a determination rests on two questions: (1) whether the state's interference has a coercive and adverse effect on parental rights, ${ }^{171}$ and (2) whether the state's interest in interfering with parental rights is a safeguard to the physical or mental health, safety, or welfare of the child. ${ }^{172}$

\footnotetext{
168. Ingraham v. Wright, 430 U.S. 651, 664 (1977).

169. Id. at 682 .

170. Patrick Henigan, Is Parental Authority Absolute? Public High Schools Which Provide Gay and Lesbian Youth Services Do Not Violate the Constitutional Childrearing Right of Parents, 62 BROOK. L. REV. 1261, 1290 (1996).

171. See Doe v. Irwin, 615 F.2d 1162, 1168 (6th Cir. 1980) (discussing cases in which the state infringed on parents' rights).

172. See In re J.P., 648 P.2d 1364, 1377 (Utah 1980) (recognizing that the "paramount consideration" is the child's welfare and parental rights are not absolute).
} 
1. The Use of Corporal Punishment in Public Schools Has a Coercive Effect on the Child-Rearing Right of Parents

For a violation of parental rights to exist, the alleged state interference must have a coercive or compulsory effect on the rights of the parents. ${ }^{173}$ "Coercion exists where the governmental action is mandatory and provides no outlet for the parents . . .."174 For example, the Supreme Court stated that a "compulsory school attendance law violated, inter alia, Amish parents' right to direct religious upbringing of their child." 175 Moreover, the Court ruled that a "law requiring public school attendance and prohibiting attendance at private parochial schools violated parental liberties."176 Finally, the Court held that a "law prohibiting the teaching of foreign languages to school children violated parental liberties." 177 "These cases strongly imply that, in order to constitute a constitutional violation, the State action at issue must be coercive or compulsory in nature." 178

Recently "courts have repeatedly made the distinction between coercive and voluntary state interference" when examining whether there is a violation of parental rights. ${ }^{179}$ For example, in Curtis, the court made this threshold determination deciding whether alleged state interference violated parental rights. ${ }^{180}$ In this case, parents brought an action against the school committee for declaratory and injunctive relief, alleging that a program of condom availability established in junior and senior high schools violated their parental rights. ${ }^{181}$ The court held that because the condoms were available to students who requested them and were available from a vending machine, the condoms did not coercively burden the parents' rights. ${ }^{182}$ In other words, the students were free to participate in the program and free to decline to participate in the program. No disciplinary action would ensue if a student did not participate.

\footnotetext{
173. See Doe, 615 F.2d at 1168 (finding no infringement on parental rights when a state "imposed no compulsory requirements or prohibition which affect rights of the [parents]").

174. Curtis v. Sch. Comm., 652 N.E.2d 580, 586 (Mass. 1995).

175. Id. (citing Wisconsin v. Yoder, 406 U.S. 205, 234 (1972)).

176. Id. (citing Pierce v. Soc'y of the Sisters, 268 U.S. 510, 534-35 (1925)).

177. Id. at 586-87 (citing Meyer v. Nebraska, 262 U.S. 390, 403 (1923)).

178. Curtis, 652 N.E.2d at 586 .

179. Henigan, supra note 170 , at 1276 .

180. Curtis, 652 N.E.2d at 586 .

181. Id. at 582 .

182. Id. at 586 .
} 
In a similar case, Doe v. Irwin, ${ }^{183}$ the court held that parental rights were not violated by a public clinic that made contraceptives available to minors because the state did not require or prohibit an activity that had a coercive or compulsory effect on the parents' rights. ${ }^{184}$ In reaching this conclusion, the court stated:

The State of Michigan ... has imposed no compulsory requirements or prohibitions which affect rights of the plaintiffs. It has merely established a voluntary birth control clinic. There is no requirement that the children of the plaintiffs avail themselves of the services offered by the Center and no prohibition against the plaintiffs' participating in decisions of their minor children on issues of sexual activity and birth control. The plaintiffs remain free to exercise their traditional care, custody and control over their unemancipated children. ${ }^{185}$

Certain courts have thus held that a violation of parental rights occurs when parents are forced to rear their children in a particular manner or accept a practice contrary to their values. ${ }^{186}$ The use of corporal punishment in public schools has a clear compulsory effect on parental rights. Corporal punishment forces minor children to be subjected to abuse without parental input and within the compulsory setting of the public school. Parents have a constitutionally protected right to intervene and prohibit the state from inflicting such punishment on their children. The use of corporal punishment provides no outlet for the parents because the child is in no position to refuse such treatment.

The administration of corporal punishment is clearly distinguishable from the above-mentioned cases, in which the courts held that no constitutional violation existed. Corporal punishment in public schools is not voluntary. Parents do not purposefully subject their children to beatings in schools, nor do children subject themselves to such treatment. In Curtis, the court held that the parents had the option to instruct their children not to participate in the condom program, thereby rendering their compulsion claim ineffective. ${ }^{187}$ Unlike Curtis, parents do not have the option to refuse the administration of corporal punishment to their

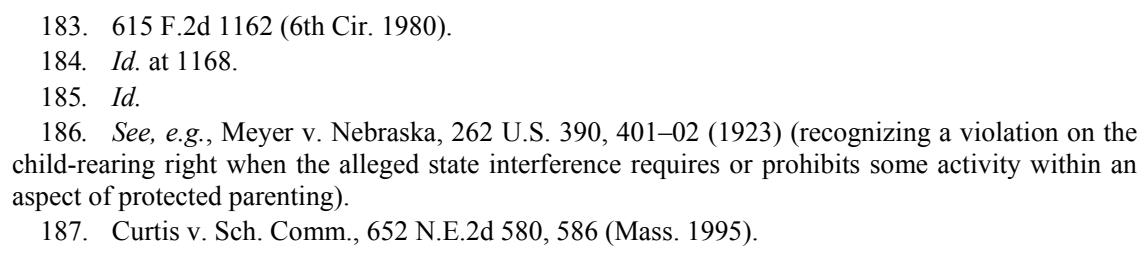

187. Curtis v. Sch. Comm., 652 N.E.2d 580, 586 (Mass. 1995). 
children. In fact, by refusing to submit to such punishment, a child risks harsher subsequent punishments. For example, in Georgia, an eightyear-old boy was paddled for failure to turn in a homework assignment, ${ }^{188}$ and when the child attempted to shield himself from a second blow of the paddle by placing his hands behind him, his principal broke the boy's arm. ${ }^{189}$ Clearly, there was no option to refuse such punishment, nor were the parents consulted before the discipline was administered. Thus, in a public school setting, parents do not have the freedom to instruct their children not to participate in the given punishments.

Critics may argue that because parents can control their child's behavior, they voluntarily choose whether the child will receive such discipline in the school. However, many children are not in the position to understand their actions and the consequences that may follow. Children are unpredictable, and oftentimes are unlikely able to make any connection between their behavior and physical punishment. ${ }^{190}$

Child development and behavior are instilled within the home. Parents have a right and "desire to pass on a cultural tradition, to inculcate religious beliefs, to foster an understanding of the good life, to promote certain values and attitudes - in short, forming the character of their children."191 Undoubtedly, "parents want the schools their children attend to support and reinforce these goals." 192 Because parents have a constitutional right to control the upbringing of their children, they set the rules and consequences in the home. Corporal punishment in public schools threatens this right. Recent research has shown that "it's important to be consistent in disciplining your child. If you don't stick to the rules and consequences that you set up, your child isn't likely to either." ${ }^{, 193}$ Corporal punishment requires parents to subject their children to inconsistent forms of punishment. For example, many parents use timeouts as a means of discipline. Timeouts are considered an effective form of discipline for a child. ${ }^{194}$ If a child was taught from ages one through five that as a consequence for misbehaving, a timeout would be

188. See supra note 62 and accompanying text.

189. Id. at 713-14.

190. See Disciplining Your Child, http://kidshealth.org/parent/emotions/behavior/discipline.html (last visited Sept. 26, 2006) ("It's important to not spank, hit or slap a child ... [because they are] unlikely to be able to make any connection between their behavior and physical punishment.").

191. R. KENNETH GODWIN \& Frank R. KEMERER, SCHOOL ChOICE TRAdEOFFS: Liberty, EQUITY, AND DIVERSITY 99 (2002).

192. Id.

193. Disciplining Your Child, supra note 190.

194. Id. 
required, the use of corporal punishment in school would seriously undermine this technique. A child struck by a wooden paddle will only feel the pain of the hit, but will not understand the connection between the behavior and the violent punishment administered. Such use of punishment may motivate the child to change his or her behavior in a negative way because everything they have learned at home has been completely taken away.

Children learn behavior and practices "by watching adults, particularly their parents." 195 Parents act according to the standards they have set in the home. "Small equivocations in parents can produce large deviations in their children . . .." ${ }^{196}$ For this reason, parents try to set a positive example for their children. Along these lines, "[s]chool personnel, especially teachers, have psychologically powerful relationships with children." ${ }^{197}$ In fact, "[1]ike parents, teachers" acceptance or rejection greatly influence how children feel about themselves, and how they behave. Children who feel accepted operate with a sense of self-worth and usually in very positive ways; children who feel rejected often act in disruptive, disrespectful and violent ways." 198 This provides teachers with the opportunity to either uphold the positive principles set in the home, or destroy their very foundation.

Corporal punishment in public schools forces parents to abandon disciplinary measures and requires them to accept other forms of discipline that may run contrary to their beliefs and standards. This is the clearest sign of governmental intrusion. "Aspects of child rearing protected from unnecessary intrusion by government include inculcation of moral standards, religious beliefs, and elements of good citizenship."199 The administration of corporal punishment offered in public schools amounts to unconstitutional interference with parental liberties because it places a coercive and compulsory burden on their rights.

\footnotetext{
195. Id.

196. Neal A. Maxwell, Settle This in Your Hearts, EnsIGn, available at http://library.lds.org (click on "magazines"; then click Ensign; then type "Settle This in Your Hearts" in the quick search; then follow the link to "Settle This in Your Hearts").

197. Alvy, supra note 38 .

198. Id.

199. Curtis v. Sch. Comm., 652 N.E.2d 580, 585 (Mass. 1995) (citing Wisconsin v. Yoder, 406 U.S. 205, 232-33 (1972); Prince v. Massachusetts, 321 U.S. 158, 166-67 (1944); Pierce v. Soc'y of the Sisters, 268 U.S. 510, 534-35 (1925); Meyer v. Nebraska, 262 U.S. 390, 401 (1923)).
} 
2. The Use of Corporal Punishment in Public Schools Undermines the Role of Parens Patriae

Even if the alleged interference on parental rights is coercive or compulsory, "the state can affect the parent-child relationship if there is a compelling reason to do so, thus limiting parental control even further." "200 "[P]arental rights, though inherent and retained, are not absolute . . . ."201 "The state, as parens patriae, has the authority and obligation to assume a parental role after the natural parent has been shown to be unfit or disfunctional; and . . parental prerogatives cannot, at that extreme point, frustrate the state in discharging its duty."202 "The concept of parens patriae allows the state to burden the constitutional rights of . . . a parent . . . in order to protect children. ${ }^{203}$ This concept "became widely accepted in the nineteenth century as the United States industrialized." 204 The poverty and child labor that materialized with new industries frequently jeopardized "the physical, mental or emotional health and safety of children.",205 "Because of this danger, .. . American courts... exercised parens patriae authority over children to protect them" and ensure their safety. ${ }^{206}$ "The state entrusted a parent with a child only so long as the parent acted in the child's best interest."207

Although there is a presumption that parents act in the best interest of their child because a parent "possess[es] what a child lacks in maturity, experience, and capacity for judgment," ${ }^{208}$ the modern state still has a significant interest in safeguarding the physical or mental health, safety, and welfare of its youth. ${ }^{209}$ The state acts in the parens patriae role when it requires children to attend school, ${ }^{210}$ orders children to participate in medical treatment, ${ }^{211}$ forbids children from engaging in

\footnotetext{
200. Henigan, supra note 170, at 1278.

201. In re J.P., 648 P.2d 1364, 1377 (Utah 1980).

202. Id.

203. Henigan, supra note 170, at 1278 (citing BLACK's LAW DiCTIONARY 1114 (6th ed. 1990)).

204. Id. (citing LEGAL RightS OF CHILDREN § 1.02, at 10 (Donald T. Kramer ed., 2d ed. 1994)).

205. Id. (citing LEGAL RIGHTS OF CHILDREN, supra note 204).

206. Id. (citing Susan B. Hershkowitz, Due Process and the Termination of Parental Rights, 19 FAM. L.Q. 245, 254-55 (1985)).

207. Id. at 1279 (citing Raymond C. O'Brien, An Analysis of Realistic Due Process Rights of Children Versus Parents, 26 CONN. L. Rev. 1209, 1216 (1944)).

208. Parham v. J.R., 442 U.S. 584, 602 (1979).

209. See Michael J. Florio, An Abused Child's Right to Life, Liberty, and Property in the Home: Constitutional Approval of State Inaction, 92 W. VA. L. REV. 175, 178 (1989) (discussing the state's stake in a child's welfare).

210. See Wisconsin v. Yoder, 406 U.S. 205, 213 (1972) (discussing the state's power to educate its citizens).

211. See Jacobson v. Massachusetts, 197 U.S. 11, 26 (1905) (discussing authority and power of
} 
certain types of labors, ${ }^{212}$ denies children the right to marry, ${ }^{213}$ and prohibits the sale of pornographic material to them. ${ }^{214}$

The Supreme Court has recognized that the state can usurp parental rights to protect the physical, mental, and emotional health of children. ${ }^{215}$ In Prince, the Court upheld the conviction of a parent who permitted one of her children to sell copies of religious publications in violation of Massachusetts labor laws. ${ }^{216}$ In reaching its conclusion, the Court stated that

[i]t is the interest of youth itself, and of the whole community, that children be both safeguarded from abuses and given opportunities for growth into free and independent well-developed . . citizens . . . . [Therefore] the state has a wide range of power for limiting parental freedom and authority in things affecting the child's welfare ....

Parham v. J.R. illustrates the states' parens patriae interest in the health and welfare of a child. ${ }^{218}$ In this case, the Court recognized that "some parents may at times be acting against the interests of their children," although "parents generally do act in the child's best interest." 219 In Parham, both the majority and the dissent concluded that parents do not have absolute rights to determine the destiny of their children because a state may override a parental decision when the physical or mental health of a child is jeopardized. ${ }^{220}$ Thus, it is imperative to this analysis to determine whether the state's interest in administering corporal punishment in public schools is a safeguard to the physical or mental health, safety, or welfare of the child. Obviously, "a

the state to regulate public health).

212. See, e.g., Prince v. Massachusetts, 321 U.S. 158, 170-71 (1944) (sustaining the conviction of the guardian of a nine-year-old girl for violating the Massachusetts Child Labor Law).

213. See, e.g., Moe v. Dinkins, 533 F. Supp. 623, 630-31 (S.D.N.Y. 1981) (sustaining New York's requirement of parental consent for marriages of persons between the ages of fourteen and eighteen), aff'd, 669 F.2d 67 (2d Cir. 1982).

214. See, e.g., Ginsberg v. New York, 390 U.S. 629, 637-43 (1968) (sustaining a New York statute making the act of knowingly selling pornographic materials to anyone under the age of seventeen unlawful).

215. See Prince, 321 U.S. at 166 (noting that the state "may restrict the parent's control by requiring school attendance, regulating or prohibiting the child's labor, and in many other ways").

216. Id. at 171 .

217. Id. at $165,167$.

218. See 442 U.S. 584, 587 (1979) (presenting the question on appeal as what process is constitutionally due when parents or a guardian seek state administered institutional mental health care for a minor child).

219. Id. at 602-03 (citing Robert M. Rolfe \& Anne v. MacCintock, The Due Process Rights of Minors "Voluntarily Admitted" to Mental Institutions, 4 J. PSYCHIATRY \& L. 333, 348-49 (1976)).

220. Id. at $604,630$. 
State's interest in universal education . . . is not totally free from a balancing process when it impinges on fundamental rights and interests."

If the Ninth Amendment provides a source of protection for parental rights, then the state must have a compelling reason to inflict corporal punishment in public schools. "A state's interest in protecting the welfare of children sometimes outweighs the childrearing right of parents when there is evidence that the state needs to protect children."222 However, when there is insufficient evidence supporting the state's right to infringe upon the parental relationship, the Court will conclude that the parents' rights outweigh the state's interest. ${ }^{223}$

Does the use of corporal punishment in public schools benefit the children in any way? Unfortunately, state governments routinely investigate suspected occurrences of child abuse, and, in appropriate cases, a court order can either limit or terminate parental rights to the custody of minor children. ${ }^{224}$ Interestingly enough, when the state, as parens patriae, fails to protect the child from parent's physical abuse, a constitutional violation occurs. ${ }^{225}$ Because of this mandate, the role of parens patriae is clearly beneficial to the child because it protects his interests in the home, particularly from physical abuse. However, who protects the child when he enters the school building? Does a state's role as parens patriae allow the state to administer the very punishment it attempts to prohibit in the home? Without the existence of a compelling state interest, maintaining corporal punishment in public schools is a clear violation of the child-rearing rights of parents.

Assuming the natural parents are shown to be fit and functional in rearing their child, the state cannot prove the existence of a compelling interest in maintaining corporal punishment in public schools. The state can only impair the rights of parents to protect the safety and welfare of

221. Wisconsin v. Yoder, 406 U.S. 205, 214 (1972) (citing Pierce v. Soc'y of the Sisters, 268 U.S. 510, $535(1925))$.

222. Henigan, supra note 170 , at $1280-81$.

223. See Yoder, 406 U.S. at 234 (deciding that the State of Wisconsin had produced insufficient evidence of harm to Amish children removed from compulsory education two years early to support the overriding of the parents' decision).

224. See, e.g., State ex rel. Miller v. Locke, 253 S.E.2d 540, 542 (1979) (upholding the constitutionality of a statute permitting the removal of a child from his home for up to ten days where there exists both an imminent danger to the child and no reasonable alternatives to removal).

225. 42 U.S.C. $\$ 1983$ (2000). The statute states that:

Every person who, under the color of any statute, ordinance, regulation, custom, or usage, of any State ... subjects, or causes to be subjected, any citizen of the United States or other person within the jurisdiction thereof to the deprivation of any rights, privileges or immunities secured by the Constitution and laws, shall be liable to the party injured ... 
the child. "A natural parent who has demonstrated sufficient commitment to his or her children is thereafter entitled to raise the children free from undue state interference." 226 The Supreme Court has held "that there exists 'a private realm of family life which the state cannot enter.",227 Thus, when the government intrudes on choices concerning the nonabusive disciplinary measures of the household, it has clearly entered this "private realm."

The use of corporal punishment does not protect the welfare of children. To the contrary, corporal punishment, as a teaching tool, is simply ineffective, or, at best, no more effective than nonviolent disciplinary methods that do not carry the risk of individual or societal harm. ${ }^{228}$ Corporal punishment as a teaching tool undermines educational policies as a whole. The Supreme Court has noted that "teachers shall be of good moral character . . . and that nothing be taught which is manifestly inimical to the public welfare."229 "Physical cruelty and emotional humiliation not only leave their marks on children, they also inflict a disastrous imprint on the future of our society." ${ }^{230}$ In other words, when a child attends school, not only does he risk being damaged personally, but also the future of our society is subjected to risk. When the state, acting in a parens patriae role, permits the administration of corporal punishment in public schools, it is clearly not trying to ensure a child's health and welfare are protected. Instead, it penetrates the safety and security created in the home and disrupts a child's formative years.

\section{CONCLUSION}

Although states have made significant progress in reducing the incidence of corporal punishment in public schools since Ingraham, children continue to be physically abused at school every year. In addressing the United States Congress, Representative Major R. Owens, chairman of the House Subcommittee on Select Education, stated that: "Every year an estimated one million American school children are beaten, pinched, slapped, punched, whipped, paddled, thrown against walls, stuck with pins, locked in closets, forced to eat noxious substances, and abused in countless other creatively sadistic ways by

\footnotetext{
226. Hodgson v. Minnesota, 497 U.S. 417, 447 (1990) (plurality opinion).

227. Id. (quoting Prince v. Massachusetts, 321 U.S. 158, 166 (1944)).

228. See Pollard, supra note 34 , at 575 (discussing the consequences of corporal punishment).

229. Pierce v. Soc'y of the Sisters, 268 U.S. 510, 534 (1925).

230. Alice Miller, Every Smack is a Humiliation, PROJECT NOSPANK (1998), http:// www.nospank.net/miller3.htm.
} 
teachers and school administrators across the country."231 The harms to children as a result of corporal punishment include lower self-esteem, depressed cognitive development, lower scholastic achievement, increased rates of violence against themselves and others, increased drug abuse, increased psychological and physical illnesses, and a likelihood of future violence when they become adults. ${ }^{232}$ The Supreme Court's refusal to resolve the conflict over corporal punishment in public schools perpetuates the uncertainty over children and parents' legal rights.

Fortunately, a substantial justification exists for recognizing a fundamental parental right under the Ninth Amendment of the United States Constitution. This inherent right is the most obvious example of rights "retained by the people." 233 "The fact that no particular provision of the Constitution explicitly forbids the State from disrupting the traditional relation of the family - a relation as old and as fundamental as our entire civilization - surely does not show that the Government was meant to have the power to do so." 234

Corporal punishment in public schools unreasonably interferes with the liberty of parents and guardians to direct the upbringing and education of children under their control. Corporal punishment forces minor children to be subjected to abuse without parental input and within the compulsory setting of the public school. "It is cardinal with us that the custody, care and nurture of the child reside first in the parents, whose primary function and freedom include preparation for obligations the state can neither supply nor hinder." 235 The use of corporal punishment in public schools unconstitutionally abridges parents' right to direct the upbringing of their children because it forces parents to accept the emotional and physical marks that corporal punishment leaves on their children. The state's interest in administering corporal punishment in public schools is not a safeguard to the physical or mental health, safety, or welfare of the child. Thus, because the state does not have a compelling reason to govern the use of it, any such administration violates the United States Constitution.

Although Ingraham v. Wright precluded federal constitutional challenges to corporal punishment based on the Eighth and Fourteenth

231. Hearing on Corporal Punishment: Hearing on H.R. 1522 Before the Subcomm. on Select Educ. of the H. Comm. on Educ. \& Labor, 102d Cong. 1 (1992) (statement of Rep. Major R. Owens, Chairman, Subcomm. on Select Educ. of the H. Comm. on Educ. \& Labor).

232. See supra Part II.A.1 (describing how corporal punishment affects children).

233. U.S. CONST, amend. ix.

234. Griswold v. Connecticut, 381 U.S. 479, 495-96 (1965) (Goldberg, J., concurring).

235. Prince v. Massachusetts, 321 U.S. 158, 166 (1944). 
Amendments, a federal cause of action based on the Ninth Amendment remains, and thus, the continuing legal battle against corporal punishment should be revisited under this approach. 